\title{
Természetvédők és kutatók ismeretei az eurázsiai hód kapcsán a Kárpát-medencében II.: táplálkozás, építés, élőhelyválasztás, ismeretterjesztés
}

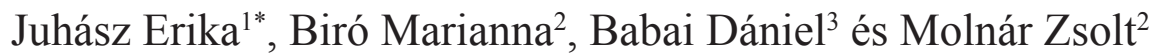 \\ ${ }^{1}$ Eötvös Loránd Tudományegyetem, Növényrendszertani, Ökológiai és Elméleti Biológiai \\ Tanszék, 1117 Budapest, Pázmány Péter stny. 1/C \\ ${ }^{2}$ Ökológiai Kutatóközpont, Ökológiai és Botanikai Intézet, \\ 2163 Vácrátót, Alkotmány u. 2-4. \\ ${ }^{3}$ Bölcsészettudományi Kutatóközpont, 1097 Budapest, Tóth Kálmán u. 4. \\ E-mail: erikamaria.juhasz@gmail.com
}

\begin{abstract}
Összefoglaló: Természetvédelmi szakemberek és kutatók eurázsiai hóddal kapcsolatos tudásanyagát vizsgáltuk interjúk segítségével. Tanulmányunk első részében a hód elterjedésével, életnyomaival, az együttélés lehetőségeivel és az elhullás okaival foglalkoztunk (Juhász et al. 2019). A második részben a hód életmódjával, valamint az ismeretterjesztéssel és a helyi lakosok adatközlők által érzékelt tudáshiányával kapcsolatos kérdésekre kapott válaszokat mutatjuk be. Az adatközlők 26 nemzetség fásszárú fajainak hasznosítását, 19 lágyszárú taxon fogyasztását és 15 lágyszárú taxon hódgátba, hódvárba való beépítését figyelték meg. Segítségükkel részletes információkat gyüjtöttünk a faj gátépítési, várépítési és élőhelyválasztási szokásainak élőhelyi adottságokkal való összefüggéseiről. Ezen információk jól kiegészíthetik a terepi felmérések eredményét, valamint segíthetik egyes jelenségek jobb megismerését és újabb terepi kutatások megalapozását. A helyi emberek tudásanyaga kapcsán az adatközlők által érzékelt hiányosságok rávilágítanak arra, hogy hóddal kapcsolatos ismereteket is érdemes a vizes élőhelyekről szóló általános ismeretterjesztésbe belefoglalni.
\end{abstract}

Kulcsszavak: Castor fiber, szakértői tudás, strukturált interjú, ökoszisztéma-mérnök, visszatelepítés

\section{Bevezetés}

Az eurázsiai hód (Castor fiber Linnaeus, 1758), valamint a Castor nemzetség másik recens képviselője a kanadai hód (Castor canadensis Kuhl, 1820) ökoszisztéma-mérnök fajok, egyes tevékenységeikkel képesek jelentős mértékben átalakítani saját élőhelyüket, ezzel számos más élőlénycsoportra és az ökológiai folyamatok széles spektrumára gyakorolnak jelentős hatást (Wright et al. 2002, Rosell et al. 2005, Law et al. 2017). A hód tájátalakító tevékenysége nemcsak a 
természeti területekre lehet befolyással, hanem a helyi ember életére is (Enck et al. 1992, McKinstry \& Anderson 1999). A helyi ember életére gyakorolt hatások az élőhelyek által nyújtott ökoszisztéma-szolgáltatások megváltoztatásán keresztül érvényesülnek (Santo et al. 2017, Ulicsni et al. 2020). Egyes területeken a hód megjelenése ember-vadvilág konfliktusok kialakulásához vezethet (Payne \& Peterson 1986, Valachovič 2014, Campbell-Palmer et al. 2015, Vorel et al. 2016). Ez más országokhoz hasonlóan Magyarországon is megfigyelhető (Czabán \& Gruber 2018, Juhász et al. 2019). Mindezek alapján a faj életmódjának megismerése, a szakmai tudáshiány, valamint a helyi lakosok tudáshiányának feltárása és pótlása természetvédelmi szempontból és az ember-vadvilág konfliktusok szempontjából is fontossággal bír. A hód táplálékválasztásával, építési szokásaival és élőhelyválasztásával kapcsolatos ismeretek bővítésével átfogóbb képet kaphatunk a faj tevékenységének jelenlegi és várható következményeiről egymástól jelentősen eltérő területek esetén.

A nemzetközi szakirodalom gazdag a hód életmódját vizsgáló publikációkban. Számos, a kontinens más országaiból származó információ áll rendelkezésre a rágáspreferencia és a táplálékválasztás (Nolet et al. 1994, Haarberg \& Rosell 2006, Krojerová-Prokešová et al. 2010, Law et al. 2014, Vorel et al. 2015), a gát- és várépítés (Hartman \& Törnlöv 2006, Fustec \& Cormier 2007, Danilov és Fyodorov 2015), továbbá az élőhelyválasztás és élőhelyhasználat (Fustec et al. 2001, Fustec et al. 2003, John \& Kostkan 2009, John et al. 2010) témájában. Ezzel szemben a faj Kárpát-medencébe való visszatérése óta eltelt alig három évtized alatt kevés hasonló kérdésköröket vizsgáló, magyarországi terepi felméréseken alapuló tudományos publikáció (Varju \& Jánoska 2015), illetve szakdolgozat (Czabán 2003, Právics 2012, Juhász 2017, Mátrai 2019) született. Ezért ismereteinket a kutatók, a természetvédelmi, vízügyi és erdészeti szakemberek, valamint a tájban élő helyi lakosok tapasztalati tudásának szintetizálása jelentősen gazdagíthatja (Juhász et al. 2017, Juhász et al. 2019, Ulicsni et al. 2020, Babai et al. 2019).

Kétrészes tanulmányunkban természetvédelmi szakemberek és kutatók eurázsiai hóddal kapcsolatos ismereteit vizsgáljuk. Az első részben a faj elterjedését, a kolonizációt, az életnyomokat, az ismert konfliktustípusokat, a konfliktusmegelőzési és -mérséklési lehetőségeket, az együttélés lehetőségeit, a gyérítés témakörét, a természetes ellenségeket és az elhullás okait mutattuk be (Juhász et al. 2019). A második (jelen) részben a faj táplálkozását, építö-tevékenységét és élőhelyválasztását vizsgáló kérdéseinkre kapott válaszokat elemezzük. Emellett külön alfejezetekben foglalkozunk azzal, hogy adatközlöink szerint hogyan tájékozódhat a helyi lakosság a hódról, valamint milyen tudáshiány jelentkezik a faj kapcsán a helyi lakosság körében. 
Kutatásunk célja a terepen sokat dolgozó szakemberek jelentős mennyiségü tapasztalati tudásanyagának feltárása, a nem szisztematikusan gyült, és korábban többnyire nem is publikált információk halmazának összegyüjtése, rendszerezése és a napjainkban jellemző narratívákkal együtt történő közlése.

\section{Anyag és módszer}

Magyarország területét a hivatalos természetvédelem intézményrendszere tíz nemzeti park igazgatóság müködési területére osztja (http1). A hazai természetvédelem szerkezetét követve a hódokkal kapcsolatos szakmai tudás feltárását e tíz térség köré szerveztük. Mivel az összes térséget megfelelően kívántuk reprezentálni, ezért minden nemzeti park igazgatóság esetében egy-egy természetvédelmi szakmai vezetőt (zoológiai referenst, osztályvezetőt, igazgatóhelyettest, igazgatót) kértünk meg arra, hogy ajánljon 4-4 személyt, aki gyakorlati természetvédő vagy kutató, a nemzeti park igazgatóság müködési területén él vagy dolgozik (nem feltétlenül a nemzeti park igazgatóság munkatársa), és feltételezhető, hogy azok között a szakemberek között van, akik a térségben a legtöbbet tudják a hódról. További 9 magyarországi adatközlőt (5 kutatót, 2 nemzeti park igazgatósági alkalmazottat, valamint 2 szakirányú végzettséggel rendelkező, ökoturizmussal és természetvédelmi célú ismeretterjesztéssel foglalkozó személyt) más adatközlőink többszöri javaslata és előzetes ismereteink alapján vontunk be a kutatásba. A szélesebb, Kárpát-medencei kitekintés érdekében 6 romániai magyar szakembert is felkértünk kérdéseink megválaszolására. Kutatásunk során összesen 55 szakemberrel (49 magyarországi, 6 romániai) készítettünk strukturált interjút. A strukturált interjú Newing (2010) alapján egy előzetesen definiált kérdésekből álló interjúfonál szerint halad, melyet a kutatást végzők azonos módon prezentálnak a megkérdezetteknek, az így egységesített (uniformizált) interjú-kontextusnak köszönhetően a módszer egyaránt alkalmas kvalitatív és kvantitatív adatok szolgáltatására.

Az adatközlők többségével (48 személlyel) 2017-18-ban, a romániai szakemberekkel és egy hazai szakértővel 2014-ben készítettünk interjút (48 interjú az elsőszerző, 6 interjú a második szerző munkájaként jött létre). 16 beszélgetés az interjúkészítő személyes jelenlétében zajlott abban a térségben, ahol az adatközlő a vizsgálati időszakban dolgozott, 39 pedig telefonon keresztül valósult meg. Az interjúk átlagosan 85 perc hosszúságúak voltak, a legrövidebb interjú 53 percig, a leghosszabb 133 percig tartott. Tanulmányunk itt közölt, második részében a hód táplálkozásával, a faj által hasznosított fás- és lágyszárú növényfajokkal, a vár- és gátépítő tevékenységgel, az élöhelyválasztással, valamint a helyi ember és a hód 
kapcsolatával foglalkozó kérdéseinket dolgoztuk fel. (Az elemzés alapját képező interjúkérdéseket az 1 . függelék tartalmazza). Az interjúkat az adatközlők hozzájárulásával diktafonra rögzítettük, majd az elhangzott információkat témacsoportonként táblázatos formába rendeztük és elemeztük. Az értékesnek vélt, egyedi információkat tartalmazó interjúrészleteket visszahallgatva idézetgyüjteményt hoztunk létre. A törzsszövegből kimaradt, de fontos idézeteket a 2. függelék tartalmazza. Az anonimitás megőrzése érdekében az interjúkból való idézés során az adatközlőket véletlenszerű kódnevekkel láttuk el $(\mathrm{H}$ = magyarországi adatközlő, $\mathrm{R}$ = romániai adatközlö, kódnevek: H1-H49, R1-R6). A Köszönetnyilvánításban adatközlöinket nem ebben a sorrendben, hanem a betürendet követve soroltuk fel.

Az eredmények állításai mögött zárójelben tüntettük fel az adatközlök általi említések számát (ld. Hartel et al. 2014). Az említésszám az információegységek adatközlők által vélt jelentőségéről, a különböző jelenségek ismertségéről tájékoztat. Az interjúfonál szabad felsoroláson alapuló (free-listing) kérdései esetében azonban nemcsak a nagyobb esetszámú, hanem olykor a csupán ritkán említett megfigyelések, vélemények is lényegesek lehetnek biológiai szempontból, mivel ritka jelenségekre utalhatnak, illetve új hipotéziseket generálhatnak.

\section{Eredmények}

Fásszárú fajok hasznositása - rágás, táplálkozás

Minden adatközlő egyetértett abban, hogy a hód hasznosítja a puhafafajokat, a füz fajok (Salix spp.) hasznosítását 55-en, a nyár fajokét (Populus spp.) 52-en említették. 51-en állították azt, hogy szerintük a hód egyes puhafafajokat gyakoriságukhoz mérten többnyire nagyobb arányban hasznosít a jelen lévő többi fásszárú fajnál, míg három adatközlő szerint ebben nincs éles különbség.

Egyesek úgy vélekedtek, hogy a hód az élőhelyen jelen levő valamennyi puhafafajt nagy mértékben hasznosítja: ,, annak idején faji szinten határoztuk a füzeket. Tehát a mandulalevelü füz, a keskenylevelü füz [azaz csigolyafüz], a fehér füz, a rekettyefüz, ezek mindegyike kedvelt csemegéje a hódnak" (H23). Mások véleménye az volt, hogy különbség van az egyes puhafafajok hasznosításának mértéke között. „,Tehát a füzfélék azok egyértelmüek, ugyanakkor például a cinerea-t, a rekettyefüzet azt annyira nem látom, hogy nagyon szeretné. Azon kevésbé látok rágásnyomot, [...] pedig az van többségében azokon a helyeken, ahol ilyen bokorfüzesek vannak" (H48). Megismertünk olyan álláspontot is, mely szerint a hód inkább a nyárfajokat részesíti előnyben: „,Nemesitett nyárból származó feketenyárszerü egyedek voltak, és azokat döntögette, pedig ott füzből minden mennyiségben volt, amilyet akart, és a füzeket nem is bántotta jóformán” (H27). 
A puhafák kivételével a legtöbb nemzetség fásszárú fajainak hasznosításával kapcsolatban megoszlottak a vélemények: az adatközlők egy része ezeken is figyelt meg rágásnyomokat, mások viszont ezek hasznosításának elmaradását tapasztalták az általuk ismert területeken (1. ábra). Az itt felsorolt 26 nemzetség hasznosítását legalább egy adatközlő megfigyelte: Salix (füz), Populus (nyár), Fraxinus (kőris), Alnus (éger), Acer (juhar), Prunus (szilva), Quercus (tölgy), Robinia (akác), Amorpha (gyalogakác), Ulmus (szil), Cornus (som), Malus (alma), Rubus (szeder), Pinus (fenyö), Pyrus (körte), Morus (eperfa), Sambucus (bodza), Juglans (dió), Corylus (mogyoró), Euonymus (kecskerágó), Fagus (bükk), Platanus (platán), Thuja (tuja), Vitis (szőlö), Carpinus (gyertyán), Betula (nyír). Néhány nemzetség esetén csak a hasznosítás elmaradásáról számoltak be: Ailanthus (bálványfa), Celtis (ostorfa), Viburnum (bangita). A nemzetség megnevezése nélkül gyümölcsfák hasznosítását kilenc, díszfákét és fenyőkét négy-négy adatközlő említette, fenyők hasznosításának elmaradását pedig öt adatközlő.

Az adatközlők egy része kivételes, egyedi esetként értékelte némely nemzetség vagy fajcsoport hasznosításának megfigyelését. A leggyakrabban a Robinia esetén fordult ez elő (7), de elhangzott ilyen vélemény a fenyők (3), az Alnus (2), a Quercus (2), az Amorpha (1), a Fraxinus (1) és a Sambucus (1) esetén is.

A Prunus nemzetség hasznosított képviselöi között szerepeltek a nemesített gyümölcsfák, a nemes szilva ( $P$. domestica), a cseresznye ( $P$. avium), a meggy ( $P$. cerasus) és emellett vadon termő fajok is, a cseresznyeszilva ( $P$. cerasifera) és a kökény ( $P$. spinosa). Az Acer nemzetségen belül a legtöbb említés a folyók hullámterében, a partszegély mentén leggyakoribb, inváziós zöld juharhoz ( $A$. negundo) kapcsolódott, de egy esetben egy másik idegenhonos faj, az ezüstjuhar (A. saccharinum), egy esetben pedig az őshonos mezei juhar (A. campestre) hasznosításáról is beszámoltak. A Fraxinus nemzetségen belül az inváziós amerikai kőris (F. pennsylvanica) és a hazai fajok, a magas és a magyar kőris $(F$. excelsior és angustifolia subsp. pannonica) hasznosítását egyaránt említették. Három adatközlö ismertetett arra vonatkozó megfigyelést, hogy a hód egy-egy területen jelentős, szerintük a puhafákat is meghaladó mértékben hasznosította a zöld juhart vagy az amerikai kőrist. „, Férfikar vastagságú amerikai köris, zöld juhar egyedek voltak bedöntve, több is. A füzfákhoz nem nyúlt hozzá meglepö módon” (H44). Az ugyancsak inváziós gyalogakác hasznosításának mértéke szintén foglalkoztatta az adatközlöket. ,,Sajnos nem tömegesen fogyasztja, de azért egy-két helyen látni, hogy belerág. [...] Lehet, hogy nem is fogyasztja, csak utat készit magának úgymond" (H17). 


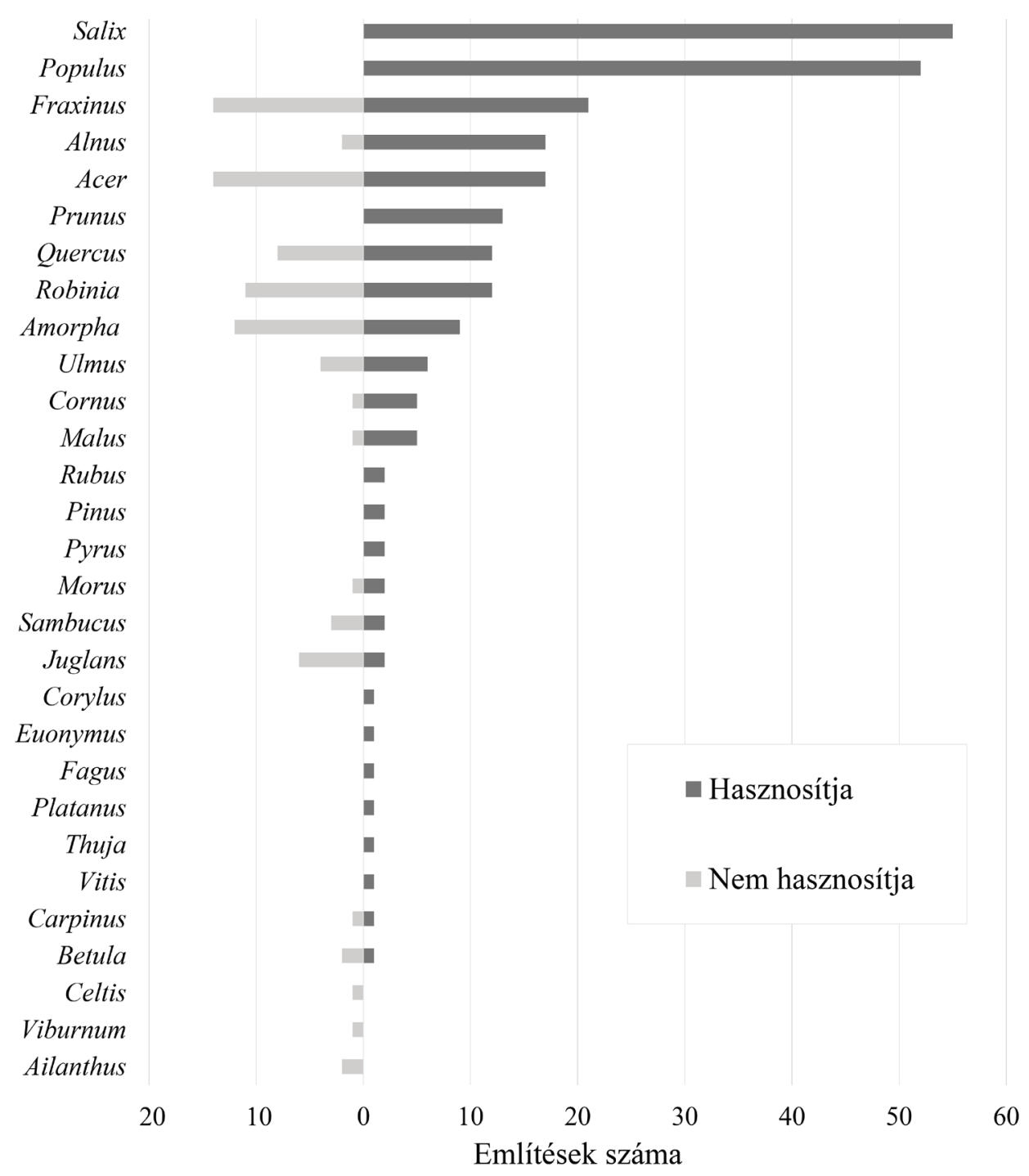

1. ábra: A fásszárú fajok hasznosításával kapcsolatos említések száma az egyes nemzetségek esetén. Az említésszám nem utal a hasznosítás valós vagy az adatközlők által vélt mértékére.

Minden adatközlő egyetértett abban, hogy a fadöntés célja elsődlegesen a fa vékony ágrendszerének elérése, mivel a hód ezen vékony ágak kérgét, háncsát (42), rügyeit (15), lombozatát (11), vékony hajtásait (9) fogyasztja. Emellett előfordul még a víz felé dőlő fák vízbe lógó ágainak (2), a szakadópartokon a kilátszódó gyökereknek (2), valamint a vágástéri hulladéknak (2) a fogyasztása is. 
Azzal kapcsolatban, hogy milyen törzsátmérőjü fákat hasznosít nagyobb arányban a hód, megoszlottak a vélemények: inkább vékony (24), vékony és közepes (6), közepes (4), közepes és vastag (2), vastag (1), nem lehet egyértelmúen megválaszolni (13). Azt, hogy a hód milyen átméröjü fákat hasznosít, a rendelkezésre álló kínálat befolyásolhatja. „Fekete nyarakból volt olyan, ahol méternél nagyobb átméröjü fa volt. [...] Körberágta szorgalmasan, egy szezon nem volt neki elég erre, és az lett a következménye, hogy a fa az kiszáradt, de még azóta sem dőlt ki. A fekete nyarak közül is inkább a comb- vagy annál kisebb vastagságúakat szokta jobban szeretni” (H23). Egy másik adatközlő így érvelt: „Ahol sok a bokorfüz, ott viszonylag kevés a kidöntött nagy fa" (H16). A megkérdezettek között volt olyan, aki ezt a vastag törzsek kidöntésére fordítandó energiabefektetés nagyságával magyarázta: „Azért nagyon nem szeret ő se sokat dolgozni a táplálékkal” (H48). Ezt a álláspontot azonban nem osztotta minden megkérdezett személy. , $A$ füzfákat azokat nagyon imádja, tehát hogy ott aztán mindent. [...], de látszik is a döntéseken, hogy ott azokra sok idöt szánt a hód" (H44).

Az adatközlők egy része szerint vannak olyan fajok, amelyek esetében a hód csak a vékony törzseket hasznosítja. Ennek kapcsán az adatközlők a kőriseket (6), a zöld juhart (5), az égert (3) és az akácot (1) említették. Vastag, idős törzsek kidöntéséről vagy megrágásáról a füz (11), a nyár (6) és a tölgy (2) esetén számoltak be. „Inváziós fafajoknál a fiatal, ilyen karvastagságú egyedeket dönti. Ott nem tapasztaltam olyat, hogy mondjuk nekiállt volna egy ilyen combosabb körisnek vagy juharnak” (H44). „Égernél láttam már húsz-harminc centiset is kidöntve. [...] Föleg olyan helyen láttam ezt, ahol több volt az ilyen invaziv fafaj, és akkor azokhoz nem annyira nyúlt" (H34).

Néhányan azt figyelték meg, hogy egyes fajok kidöntött vagy éppen csak megkezdett törzsét a puhafákkal ellentétben a hód otthagyta, nem dolgozta fel, ilyet észleltek a kőris (1), a tölgy (1), a fenyő (1) és a dió (1) kapcsán.

A holtfa vagy fából készült tárgyak megrágása ritka, de több példa is volt már csónak károsítására (2). Továbbá előfordult horgászpad lábának (1), csónakleeresztő csúszdának (1) és lépcsőnek (1) a megrágása is, valamint egy müemléki jellegü vízimalom lapátja szintén hód általi befaragás következtében sérült meg (1).

\section{Lágyszárú fajok fogyasztása}

A lágyszárúakkal való táplálkozást leginkább szakirodalomból ismerték, 48 adatközlő gondolta úgy, hogy a hód fogyaszt lágyszárúakat. „Nyáron inkább azért tünik el az emberi szem elöl, mert hogy nem a fákat rágja, hanem a zöldet”(H11). „Látjuk, hogy a fákhoz nem nyúlt hozzá, mert nincsenek friss rágásnyomok, ellenben viszont le van legelve a növényzet" (H44). 
A lágyszárúfogyasztással kapcsolatos megfigyelések az alábbi taxonok esetében fordultak elő: Typha spp. (gyékény, 4), Poaceae (füfélék, 2), Carex spp. (sás, 1), Phragmites australis (nád, 1), Butomus umbellatus (virágkáka, 1), Sagittaria sagittifolia (nyílfü, 1), Nuphar lutea (vízitök, 1), Trapa natans (sulyom, 1), Glyceria sp. (harmatkása, 1), hínárfélék pontosabb megnevezés nélkül (1), Polygonum aviculare (madárkeserüfü, 1), Fallopia japonica (japánkeserüfü, 1) és Solidago spp. (aranyvesszö, 1). „Sokszor látok tövestöl kirántott gyékényt, ami meg van rágva [...] Bent ült a virágkákás közepében, és ott rágta a virágkákát [...] Sokszor megy ki uszadék közepére, oda viszi a kis ennivalóját” (H22). „Itt a Rábca folyó partján a madárkeserüfü nevü, ilyen utakon felverödö gyomot vagy taposott helyeken felverődő gyomot, azt látjuk, hogy elöszeretettel fogyasztja. Kimászik, és egy szabályos félkör alakban folytatja a legelést, ami a napok alatt egyre szélesedik" (H10).

A termények közül a kukoricát (Zea mays, 36), egyéb gabonaféléket (6), repcét (Brassica napus, 5), cukorrépát (Beta vulgaris subsp. vulgaris var. altissima, 4), napraforgót (Helianthus annuus, 3), kerti veteményt (3) és lucernát (Medicago sativa, 2) említették. , Úgy tünt, hogy kijárnak a napraforgóföldre a vizböl. A napraforgót mindenestül elhozzák, szárastul, fejestül, és a vízben több tányér megrágott napraforgót találtunk meg szárdarabokat, amiket már fölaprított. Úgyhogy gondolom, hogy a levelét fogyaszthatja. Levelet nem találtunk egyet sem meg. A tányérba azért bele volt rágva. Tehát voltak ilyen dirib-darab tányérok" (H22).

\section{Gátépités: kanadai vagy eurázsiai?}

35 adatközlő látott már hódgátat. Az eurázsiai hód gátjaival elsősorban keskeny csatornák, patakok mentén találkoztak (19). Szélesebb vízfolyások mentén ez a típusú építkezés ritka, mindössze egy kivételes esetről számoltak be (2): „, Hát egy olyan fél Mosoni-Duna szélességü viztestet zártak el keresztbe’. Nagyon látványos nagyon szép, még a Google Earth-ön is lehetett látni" (H22). Van olyan nemzeti park igazgatóság, melynek területén a hód csak elvétve, nagyon kevés területen épít gátat (Duna-Dráva, Hortobágyi és Kiskunsági Nemzeti Park Igazgatóság), illetve olyan is, ahol az adatközlök egyike sem tapasztalt gátépítést (Körös-Maros Nemzeti Park Igazgatóság). Érdekes jelenség, hogy ezekben a térségekben, - de még akár olyan térségekben is, ahol a gátépítés jellemző bizonyos víztesteken - az adatközlők egy része (10) olvasmányélményeire vagy másoktól hallott információkra hivatkozva azt állította, hogy az eurázsiai hód semmilyen körülmények között nem épít gátat. További három adatközlő nem zárta ki ugyan a gátépítés lehetőségét, de nem is tartotta azt a fajra jellemzőnek. Két olyan esetre is fény derült, amikor egy hódcsaládot gátépítése miatt kanadai hódnak hittek. 
Az eurázsiai hód gátépítésének céljaként az adatközlők legtöbbször a megfelelő vízmélység biztosítását és/vagy a vízszint stabilizálását nevezték meg (33). Említésre került még a kotorék bejáratának víz alatt tartása (9), a ragadozók előli rejtőzködés, menekülés (7), az úszva történő közlekedés lehetőségének biztosítása (5), a vízfelület megnövelése által nagyobb táplálékmennyiség könnyebb elérése (4), a vízcsobogás megszüntetése (2) és a sodrás csökkentése (1). Egy adatközlő azt is megjegyezte, hogy ezen tevékenység hatására a hód számára további, táplálékként szolgáló növényfajok jelenhetnek meg a területen.

Egy 2 méternél magasabb, 8-10 éves hódgátról is információt kaptunk. A legtöbb térségben ilyen idős hódgátról nem számoltak be, ugyanis a gátak rendszeresen elbontásra kerülnek (12 említés, 5 térség), de a hód hamar visszaépíti ezeket (2). „A hódgátat így emberi erővel nem nagyon érdemes bontogatni, [...] az elsö éjszaka újjáépiti határtalan szorgalommal” (H10).

Vár vagy kotorék?

Mivel a hódvár fogalma többféle megjelenést takar, 'vár' alatt értettünk minden ágakból álló építményt, a gátak kivételével. Vár lehet tehát a kotorék befedésére, tetejének erősítésére vagy bejáratának elrejtésére használt ághalom is. Az egyik adatközlő a hódvárat a következőképpen jellemezte: „Úgy néz ki a felületes szemlélönek, hogy ott van, mint egy gallykupac, amit a favágók ottfelejtettek a vízparton, de hogyha egy kicsit jobban ránézünk, akkor lehet mellette látni a legalább két-három fényesre taposott feljárót, frissen kihordott iszapot, és [...] a frissen rágcsált fadarabokat is" (H10).

A hódvár alakja, megjelenése és szerkezete kapcsán többek között a következő gondolatok fogalmazódtak meg (különböző adatközlők által használt, hasonló jelentésü tartalmak felsorolása: '/’): gallykupac (12), kúp/kemence alakú (2/2), gallyak rendezetlen halmaza (4), egy méternél magasabb építmény (7), több köbméter nagyságú építmény (7), gondosan összerakott (1), nehéz megbontani (1), járni lehet rajta (1), róka/pézsmapocok várhoz hasonló (3/1), olyan, mint egy sasfészek/szalmakazal/rőzsekupac/hangyaboly/vágástéri hulladékkupac/kunyhó $(1 / 1 / 1 / 1 / 1 / 2)$, a meder és a partél találkozásánál található (2), a bejárat a víz alatt van (6), a lakóüreg szárazon van (2), bejárata széles (2). A legnagyobb hódvár, amelyröl beszámoltak 2,5 méter magas volt.

Egy adatközlő a várépítés folyamatát is megfigyelte: „,Egyszer lefényképeztem egy olyat, amikor beszakadt az üregük teteje [...] Még nem volt idejük teljesen kijavitani, de már nekiláttak, és elkezdték pakolni körbe az üreg körül az ágakat. Tehát olyan volt, mint egy nagy sasfészek. [...] Nem volt még semmi kitapasztás. [...] Ha közelebb mentem akkor láttam, hogy ezek igazából hódrágta ágak, és van a közepében egy ilyen harminc centi átméröjü üreg. És amikor felé hajoltam és belenéztem, mi van benne, bent voltak a hódok is" (H22). 
Csupán egy adatközlő mondta azt, hogy az általa ismert területeken a hódcsaládok mindig építenek várat, négy adatközlő szerint pedig a kanadai hóddal szemben az eurázsiai hód esetén a várépítés nem jellemző vagy nagyon ritka. Akik találkoztak már valamiféle ,várszerü” építménnyel, azok a várépítés célját többféleképpen határozták meg. 21 adatközlő szerint olyan helyen kell a hódnak mindenképpen várat építenie, ahol másként nem lehetne olyan kotorékot kialakítani, mely stabil és melynek legmagasabb pontja szárazon, a víz szintje felett marad. Ennek oka lehet a lapos part (18), a vízzel telített talaj (4) és/vagy a talajszerkezet (2). ,Nem mindenhol van elegendö földtérfogat, amibe furkálhat. Vagy azért, mert a talajvizszint alatt lenne, vagy egyszerüen teljesen sík területen van” (H42). „A Hanságban alacsonyak a partok, és ezért épitenek várat többnyire. Öt-hatszáz méterenként látni egy-egy nagyobb várat. A Felsö-Tiszán egy darab várat nem találtam, mert ott olyan magasak a partok, hogy ott egyszerüen elfér benne az üreg, és nem szakad be a teteje." (H11).

Mások megfigyelései szerint a hód a már meglévő kotorékaira épít várat a beszakadás (5) vagy a vízszint ingadozása (4) miatt. Vízszintcsökkenés esetén a kotorékbejáratot el kell fednie (1), vízszintemelkedés esetén a lakóüreget a vízszint felett kell tartania (1). További felvetések és vélemények is megfogalmazódtak, melyek szerint a várépítés a biztonsággal (3), a családalapítással (3), tanult viselkedésformával (2), a sodrással (1), az építőanyag elérhetőségével (1) vagy a medermorfológiával (1) függ össze. Két adatközlő kiemelte, hogy a hód általi területfoglalás idejére nem következtethetünk az alapján, hogy mekkora építmény fedi a kotorékrendszer tetejét. , Vannak hódok, amelyek elsöre iszonyat nagy várat raknak.” (H41). „Olyan több is van, ahol 6-8 éve ugyanott laknak, és maximum jobbra vagy balra költöznek a kijárattal, de a tetején, a magaspart tetején nincsen semmi gally." (H23).

Egyes megkérdezettek szerint a várak vagy kotorékok akár 5-10 éven át (13), vagy annál hosszabb időn keresztül is (2) lakottak lehetnek, mások szerint a hód ezeket 1-3 évente vagy akár annál gyakrabban váltogatja (8). Olyan vélemény is megfogalmazódott, mely szerint egy kotorék használatának időtartama az élöhelytől, a víz dinamikájától, a vízfolyás mederformáló erejétől is függ: ,Hát úgy pár évig biztos megvannak. [...] A folyón szerintem nagyobb a dinamika, és ott mintha szerintem jobban változtatnának" (H32).

\section{Élöhelyválasztás}

A territórium helyének kiválasztása során a hód 16 adatközlő szerint előnyben részesíti azokat a területeket, ahol legalább egy rövid szakaszon meredekebb, magasabb part is megtalálható. Egy adatközlő úgy vélekedett, hogy az a legjobb, ha változatos a partjelleg a territóriumon belül, hármuk véleménye pedig az volt, 
hogy a part bizonyos meredeksége fölött nem vagy kisebb eséllyel foglalja el a hód a területet. Öt adatközlő szerint az épített, kövezett partokat, egy szerint a kavicsos lapospartokat nem foglalja el a hód. Tízen említették, hogy kedvezőbb a hód számára az, ha a vízszintingadozás mérsékelt.

A faj megtelepedése szempontjából fontos lehet a táplálék elérhetősége - mind a fásszárú (27), mind pedig a lágyszárú tápláléké (4) -, valamint a fásszárú fajösszetétel és a parti sáv szerkezete (17). Három adatközlő szerint a hód megjelenése szempontjából a növényzet nem limitáló tényező. Valamilyen minimális vízmélység meglétét 14-en vélték fontosnak, a zavarás hiányát pedig 19-en. Ezzel szemben három adatközlő tapasztalatai azt mutatták, hogy a jelentős emberi zavarás, állandó emberi jelenlét vagy a városi környezet sem zárja ki a megtelepedés lehetőségét. ,Az itteni állatoknak egy jó része olyan területen van, ahol folyamatos csónakforgalom van, folyamatos emberi jelenlét, és horgászok közé odamegy a horgászhelyre" (H17).

Azzal kapcsolatban, hogy milyen szélességü vízfolyást részesít előnyben, megoszlottak a vélemények. A szélesebb folyók és a keskenyebb vízfolyások mellett egyaránt hét-hét adatközlő érvelt, ugyanakkor három adatközlő szerint a szélesség nem limitáló tényező. (A kérdés megválaszolását nehezíti, hogy a területek elfoglalásának sorrendjét a faj adott térségen belüli terjedésének iránya is befolyásolhatta.) Az a megállapítás is többször hangzott el, hogy a hód kifejezetten a folyók mellékágait kedveli (3). Szintén három adatközlő állította azt, hogy a faj tartósan jelen van az adott térség legtöbb holtágán is. 14 adatközlő szerint kerüli a nagyon erős sodrást, hat szerint pedig az állóvizeket. Ketten vélték úgy, hogy a sodrásnak nincs jelentősége.

A magyarországi visszatelepítések egy része holtágakon, álló- vagy lassú folyású vizek mentén történt. Hat adatközlő azonban arról számolt be, hogy a hód a telepítési helyszínek egy részéről hamar elvándorolt: ,, Most azt kell tudni, hogy a telepitést követö másfél év múlva a hetven százalékuk elköltözött [...] A helyzet az, hogy nem a Nagy-Dunára mentek ki, hanem inkább a mellékágakra, holtágakra. Ahová kiengedték, ott lapos part volt, meg néhány füzfa állt a parton. Ök meg inkább átmentek egy kilométerrel arrébb, ahol egyik része szakadt part volt, a másikon egy nyaras, sarjadzó állapotban lévö erdő volt, füzfabokrokkal, egyebekkel" (H23). Máshol a telepítési helyszínekről csatornákra költöztek át a hódok: „,Hát eleinte úgy tünt egyébként, hogy inkább az ilyen kisebb csatornákat, tehát nem túl széles, zavartalanabb, [...] bokrokkal fákkal benött vagy övezett csatornákat kedveli. Amikor a holtágba is kitelepitették, utána nem ott jelent meg, hanem egy csatornán" (H8). Egy adatközlö szerint ennek az is lehet az oka, hogy a Bajorországból származó egyedek eredeti élőhelyükön is csatornák mentén éltek. 
Néhány további gondolat is megfogalmazódott az élöhelyválasztással kapcsolatban: A hód elönyben részesíti azokat a vizeket, amelyek télen nem fagynak be, nyáron pedig nem melegednek fel túlságosan (1), kevésbé szereti a szabályozott szakaszokat (1) és a hegyvidéki patakokat (1). A náddal benőtt szakaszokat egy adatközlő szerint kedveli, egy másik szerint elkerüli. Három adatközlő véleménye az volt, hogy a hódnak ,nincs élőhelypreferenciája”.

\section{A kotorék helyének kiválasztása}

A hód nemcsak territóriumának helyét választhatja tudatosan egy-egy víztest mentén, hanem kotorékának vagy várának helyét is a territóriumán belül. 13an emelték ki, hogy ennek során elönyben részesíti a magaspartokat, magasabb térszíneket. „Zátonynál, ilyen lapos partokon nincsen kotorék. Ilyen helyeken sokszor ilyen evőhelyek vannak, de gyakran a szemben lévö, [...] a folyó másik partján lévö meredek részen [...] ott van a kotorék." (H49). Egyesek megjegyezték, hogy az agyagos talaj (2) és a part stabilitása (2) is meghatározza azt, hogy alkalmas-e egy szakasz a kotorék kialakítására. Ketten úgy tapasztalták, hogy a kövezett részeket, épített partokat elkerüli a hód, de ennek ellentmondó megfigyelésről is beszámoltak: „Még olyan helyeken is látni az üregeit, konkrétan zárás oldalában, ami sziklából épült” (H22). 11 adatközlö figyelte meg azt, hogy a hód elöszeretettel választ olyan helyet, amelyet sürü növényzet takar, tesz nehezen megközelíthetővé, vagy olyat, amely gyökérzet rejtekében, esetleg bedőlt fák alatt található. A fásszárú és a lágyszárú növényzet minősége, mennyisége a táplálék könnyü elérhetősége szempontjából is fontos lehet a kotorék közelében (3). ,Itt [...] bármilyen fásszárú nagyon elszórtan van, és abból viszont itt kifejezetten a hódvár környékén a legsürübb az állomány. Illetve ezt a partszakaszt gyalogakác is jóval sürübben boritja be, hogy így összefüggöbb állománya van, tehát egy kicsit rejtettebb, boritottabb részen van" (H13).

Nyolcan úgy vélekedtek, hogy a kotorék melletti területen a zavarás hiánya mindenképpen fontos a faj számára, egy adatközlő szerint azonban az ottani zavaráshoz is hozzá tudnak szokni. Néhányan a kotorék előtti vízmélységet is meghatározónak tartották (4), elsősorban a kisebb, sekélyebb vízfolyások esetén. Négy adatközlő szerint a kotorék helye nem különbözik jelentősen a territórium más szakaszaitól.

A hód aktivitása és életnyomainak sürüsége is különbözhet a territórium eltérő szakaszain. Egyes adatközlők azt állapították meg, hogy a rágásnyomok (19) és a hód által felhalmozott ágak (4) rendszerint nagyobb mennyiségben találhatók meg a kotorékok és várak környékén. „, Nagy kupleráj, összevisszaság van, és körülötte meg van rágva minden." (H14). Más adatközlők tapasztalatai viszont arra mutatnak, hogy ez nem feltétlenül igaz (4), bizonyos területeken pedig kifejezetten 
ennek ellenkezője jellemző (4). „Én azt vettem észre, hogy ahol hódvár van, a hód figyel arra, hogy tiszta udvar, rendes ház legyen neki. A portáján, ahol van a vára, ott egy 100-150 méter sugarú körben nem csinál semmit. Úgy értem, ott nem látszik a döntögetés, rágásnyomok, hanem azon kívül” (H46). „Egyedül a nagy gallykupac, ami elárulja” (H17).

Két adatközlő szerint a kotorék többnyire nagyjából szemközt van a túlparti táplálkozóhellyel. A várak és kotorékok mellett általában jól kitaposott csapások, csúszdák vezetnek a partra (18), emellett pedig friss sárfelhordás nyomát (3) és egyéb életnyomokat (7) is meg lehet figyelni. „Pár év után betapasztják, sarat is hordanak rá, ami olyan [...] mintha az erdöt kiseperték volna” (H21).

\section{Épitőanyagok (vár-és gátépités együtt)}

Egyes növényfajok, növényi részek hód általi hasznosításának célja nemcsak táplálkozás, hanem építés is lehet. Az adatközlők szerint a hód a táplálkozási célú hasznosítás mellett építésre is használja a füzfajokat (6), a nyár fajokat (2), a veresgyürüsomot (Cornus sanguinea, 2) és a kökényt (1). Az adatközlök egy része inkább építési célú hasznosítást feltételez a kőrisek (3), a gyalogakác (2), a zöld juhar (1) és a rekettyefüz (Salix cinerea, 1 ) metszése vagy kidöntése esetén.

A gyalogakáccal kapcsolatban hangzott el a következő megállapítás: „Épitéshez használja. Azt már láttam, hogy a hódvárban benne van, de hogy azt lecsupaszitani, lekérgezni... Azt még nem láttam, hogy ette volna" (H46).

A hód felhasználja építőanyagként azokat az ágakat, melyeket ő metszett le (10), továbbá a területen talált letört ágakat, vékony uszadékfákat (9) és a vágástéri hulladékot (2) is. Nagyon ritkán ember által készített fa használati tárgyak is kerülhetnek az építmény elemei közé, az interjúk során extrém példaként került elő az akácból készült, megrágott villanypásztorkaró (1) és az evezőlapát (1) beépítése.

A faanyag mellett a lágyszárú növényi részek építőanyagként való hasznosítása is jellemző (16). Ennek kapcsán az adatközlők saját vagy ismerősöktől származó megfigyelésekről a következő lágyszárú fajok vagy fajcsoportok esetén számoltak be: Zea mays (kukorica, 10), Phragmites australis (nád, 4), Carex spp. (sás, 4), Typha spp. (gyékény, 3), káka pontosabb megnevezés nélkül (1), Nuphar lutea (vízitök, 1), Sium sp. (békakorsó, 1), Alisma plantago-aquatica (vízi hídőr, 1), Stratiotes aloides (kolokán, 1), Ceratophyllum demersum (érdes tócsagaz, 1), egyéb hínárfélék pontosabb megnevezés nélkül (2), Fallopia japonica (japánkeserüfü, 3), Poaceae (füfélék, 1), Lysimachia spp. (lizinka, 1), Helianthus tuberosus (csicsóka, 1). ,Amit a környezetben talál. Az egyik ilyen gát az egy szivárgó csatornán van, és ott föleg lizinkaféléket, nádat talál és abból van, illetve hínárfélékböl. Föleg érdes tócsagaz van azon a részen. A másiknál pedig 
békakorsó, keskenylevelü gyékény van föleg, vízi hidör. Ezeket láttam beépitve a gátba” (H17). ,,Ezeket így beletömködte gondosan, meg látszott, hogy ez így össze van dolgozva az egész a sárral meg a növényekkel együtt, tehát kitömte az ágak közét" (H7).

Előfordul, hogy az építményben nincs vagy alig van faanyag, és a vár vagy gát döntően lágyszárú növényi részekből készül. ,, [...] egyértelmüen nádból volt rakva, mert nem is nagyon van alkalma másból épitkezni” (H48). , Többször láttam gátat is, és egy kis patakon volt, amit kukoricával gátalt el. Tehát kukoricából és sárból épitett gátat, mert hogy a kis patak mindkét oldalán egy szántó volt, kukoricás, és ahhoz jutott könnyen hozzá” (H37). ,Sok helyen probléma az, hogy gyakorlatilag a mederig be van szántva az ártér, [...] és akkor a kukoricának a szára is pont olyan jó gátanyagnak, mint mondjuk egy darab füzfaág" (H16).

A hód iszappal, sárral tapasztja építményeit (21), olykor köveket is hord rá (3). Egyes esetekben kagylók (2) vagy pedig kavicsok (1) figyelhetők meg a vár tetején, melyeket az iszappal együtt hoz fel az állat, és ez az iszap később lemosódik (1). A müanyag beépítése ritka, elsősorban az uszadékkal együtt akad fenn a vár vagy gát oldalán (1), egyértelmü, direkt beépítést egy adatközlő tapasztalt.

Ismeretterjesztés, ismeretszerzés

A faj visszatérésének a visszatelepítések és a korai észlelések idejében jelentős médiavisszhangja volt Magyarországon (24). Hat adatközlő a „médiakampány” kifejezést használta. Néhány térségben pedig célzott ismeretterjesztés, szemléletformálás (12) folyt a hóddal kapcsolatban, elsősorban a telepítéseket koordináló WWF Magyarország szervezésében. „, Olyan tíz évig futott a Hódóra nevü munkánk, amelynek során [...] általános iskolás korosztálynak tartottunk hódismereti órákat. [...] Tehát kifejezetten a telepités vagy a hódok terjedési útvonalában lévö helyszineken zajlott ez a tájékoztatás" (H33). Ismeretterjesztö kiadványok készültek (12), táblák kerültek kihelyezésre egyes telepítési helyszínekre (3), továbbá nyilvános szabadon engedésekre is sor került (2). ,Amikor a WWF-nek a visszatelepités eseményei voltak, akkor a környékröl elég sok ember odajött, és megnézték a hódokat, meg hogy hogyan engedik ki öket. Ott rendesen fotóztak a gyerekekkel.” (H43). Ezzel szemben adatközlöinktől úgy tudjuk, hogy Romániában még a telepítési helyszínek közelében sem hívták fel a lakosság figyelmét a faj visszatérésére, nem volt a fajjal kapcsolatos ismeretterjesztés (4). ,Én már csak arra a fázisra emlékszek, amikor mindenki feleszmélt, hogy itt van a hód” (R6).

A fajjal kapcsolatban Magyarország egyes térségeiben ma is információkat szerezhetünk a médiából (13), öt adatközlő azonban azt hangsúlyozta, hogy a hód a sajtóban napjainkban inkább negatív színben tünik fel. Két adatközlő kiemelte, hogy kezdetben a faj visszatérése jelentett szenzációt, a sajtó kommunikációja 
a károk, konfliktusok jelentkezésével párhuzamosan kezdett változni. „Ebben is ugye nyomon követhetö volt, hogy elöször ilyen örvendezés volt. De hát a sajtó az ilyen. [...] Amikor elkezdtek nyilatkozni a polgármesterek, az erdészek meg a vizügyesek, akkor mindjárt elkezdték az ellenkezö értelmü nótát is fújni” (H42). „Ezek ugye befolyásolják a közvéleményt. Azóta kicsit szerintem csökkent a hódok népszerüsége" (H43).

A média olykor leegyszerüsíti, egyoldalúan mutatja be a jelenségeket, ezzel kapcsolatos személyes negatív tapasztalatról is beszámoltak nekünk: „A hírek azok mindig úgy vannak, hogy ha hír akkor legyen komoly [...] Elmondtam nekik nagyon-nagyon sok mindent a hódról. Pozitív dolgokat is. [...] És ebböl egyetlen egy mondat került be a híradóba, az, amikor mondtam, hogy okoznak károkat." (H22). A konfliktusokkal kevésbé érintett térségekben három adatközlő úgy vélte, hogy a sajtó nem érdeklődik a téma iránt vagy érdeklődése alábbhagyott.

A hód egyes térségekben említésre kerül oktatási, környezeti nevelési munka során (7), vezetett túrákon (3), helyet kap kiadványokban (2), a térség értékeit bemutató természetfilmekben (1). ,A nyilt túrának az a része, ami bemutatja az ott élö gerinceseket, a hódra is mindig kitér" (H12). Ezzel szemben más térségekben nem vagy alig jelenik meg a faj a természetvédelem kommunikációjában (19). Három adatközlő szerint ennek oka a téma kényessége, konfliktusos mivolta.

Négy adatközlő azt nyilatkozta, hogy nem érzi kiemelten fontos kérdésnek a fajjal kapcsolatos ismeretterjesztést. Az interjúk során hatan tértek ki a szemléletformálás szükségességére, két másik adatközlő azonban hangsúlyozta, hogy a kommunikációnak nem a népszerüsítésről kell szólnia. Kilencen emelték ki, hogy a természetvédelmi őrök érdeklődés vagy felmerülő problémák esetén tájékoztatást adnak. Öt adatközlő szerint a helyi lakosok elsősorban egymástól szerezhetnek információt.

A jövőben megvalósítandó ismeretterjesztés kapcsán a következő ötletek merültek még fel: ismeretterjesztő film vagy rövidfilm készítése a hódról (2), biológia-tankönyvben való megemlítés (1) és állatkertekben való bemutatás (1). „Nyilvánvalóan valamennyi természeti értékre ráférne, ahogy korábban volt a televizióban [...]. Gyakorlatilag ilyen egy perces snitteken mutattuk be hazánk természeti értékeit. Egy ilyenben mindenképpen helyet kaphatna a hód is, de nem gondolom azt, hogy kiemelném a többi, akár védett emlös közül” (H9).

Napjainkban a romániai sajtó is figyelmet fordít a fajra (6), ennek ellenére két adatközlő szerint továbbra is elsősorban ,szájhagyomány” útján terjednek a fajjal kapcsolatos információk. 
Az adatközlök által érzékelt tudáshiány a helyi lakosság körében

24 adatközlő véleménye szerint általános tudáshiány tapasztalható a fajjal és annak életmódjával kapcsolatban a helyi lakosok körében. ,Azért észre lehet venni, hogy sokáig nem volt a hód, és az átlagember, aki sosem foglalkozott vele, nem tud túl sokat róla” (H22). , Tehát ez azért ennyi idö alatt kiveszett az emlékezetböl is, tehát a nagyapám se hallott róla, annak a nagyapja se" (H9).

23-an számoltak be arról, hogy gyakori tévhit térségükben az, hogy a hód hallal táplálkozik. Mindössze egy adatközlő szerint sikerült ezt a tévhitet teljesen eloszlatni. „Hiába látják a kidőlt fákat meg a lerágott ágakat, nagyon érdekes, hogy nagyon sokan nem hiszik el még mindig, hogy növényevö. Amikor konkrétan az útárokban lévö hódhoz mentem, akkor ö két keszeget kapott a helyiektöl, amiken rajta feküdt” (H12). Az emberek olykor keverik a hódot a vidrával (5) vagy a pézsmapocokkal (2). Az adatközlők szerint főként a következő témakörök kapcsán jelentkezik tudáshiány: a faj táplálkozása (24), őshonossága (7), területhasználata, víztől való eltávolodása (4), szaporodása (2), élőhelyátalakító tevékenysége (1), védettsége (1), visszatérésében a spontán folyamat szerepe (1), valamint az eurázsiai hód és a kanadai hód közötti különbségek (4). Kilenc adatközlő kiemelte, hogy több információt kellene közvetíteni a helyiek felé a konfliktusmérséklés, konfliktusmegelőzés, együttélés lehetőségeiről. Vannak térségek, ahol a lakosság a faj jelenlétével sincsen tisztában (3).

Egyes adatközlők problémaként említették, hogy a helyiek közül sokan csak a károkat, a negatív hatásokat veszik észre a hód tevékenysége kapcsán (9), olykor pedig nehezen fogadják be az ellentétes információkat, azok nem érdeklik őket (2). „Hát szerintem ez a legfontosabb hiány, amit mondtam, hogy az élöhelyátalakitó hatása egy ilyen állatnak az mennyire fontos és értékes, de ebböl mi csak egy szeletet vagyunk hajlandóak észrevenni, azt, hogy gazdasági kár is keletkezhet" (H17). A helyiek és a turisták gyakran nem is a közvetlen gazdasági károkat, hanem a hód tevékenységét, a környezet rendezettségének csökkenését élik meg negatívan. „Nagyon sok ember - ezt a nyílt túrákon is tapasztalom - mindig ezt kérdezgeti, hogy a mi erdönkben miért van ennyi kidölt fa, hogy ez hogy néz ki, hogy ö hogy el van keseredve, hogy milyen ronda és rendetlen az erdö. És hiába mondja el az ember a holtfa jelentöségét az erdöben, nagyon-nagyon sok idö kell, hogy elteljen szerintem, hogy megértsék az emberek" (H12). 


\section{Diszkusszió}

\section{Táplálkozás}

Az adatközlőktől származó információk szerint az eurázsiai hód legalább 26 növénynemzetség fásszárú fajait hasznosítja a Kárpát-medencében. Egy másik közép-európai országban, Csehországban végzett terepi kutatás ezek közül 15 nemzetség hasznosítását igazolta: legnagyobb arányban Salix, Populus, Ulmus, Quercus, Prunus, Fraxinus, Betula, Alnus és Acer, kisebb mértékben pedig Carpinus, Cornus, Corylus, Juglans, Robinia és Sambucus (Vorel et al. 2015). Emellett pedig ugyanezen vizsgálat során négy, az adatközlők által nem említett vagy nem hasznosítottként említett nemzetség (Crataegus, Picea, Sorbus, Tilia) esetén is detektáltak rágásnyomokat (Vorel et al. 2015). Táplálékválasztással és rágáspreferenciával kapcsolatban született hazai publikációk, szakdolgozatok, diplomamunkák szintén számos puhafa-, keményfa- és cserjefaj hód általi hasznosítását igazolták Magyarország különböző térségeiben (Czabán 2003, Právics 2012, Varju és Jánoska 2015, Mátrai 2019). Az inváziós fásszárú fajok (Acer negundo, Amorpha fruticosa és Fraxinus pennsylvanica) hasznosítását itt bemutatott öszszesítésünket megelőzően már jelezték terepi felméréseken alapuló tudományos munkák (Tallósi 2013, Juhász 2017, Juhász 2018). Korábban falusi, „tájban élő” emberekkel készített interjúk eredményei is segítettek bővíteni ismereteinket a hód rágási tevékenységének témakörében (Juhász et al. 2017).

A hód a téli időszakban élelemraktárt hozhat létre, amit a jellemző életnyomok felsorolásakor nyolc adatközlő említett (Juhász et al. 2019). Azzal kapcsolatban viszont nem számoltak be megfigyelésekről, hogy abban milyen fajok ágait halmozza fel az állat. Az élelemraktár észak-lengyelországi területeken fóként Salix, Betula, Corylus, Alnus és Populus fajok ágaiból áll (Dzięciołowski \& Misiukiewicz 2002).

Adatközlőink döntő többsége úgy vélte, hogy a hód nagyobb mértékben hasznosítja a puhafafajokat más nemzetségek képviselőinél. A rágáspreferencia kizárólag terepi vizsgálatok alapján, az adott területen jelenlévő kínálatnak és annak hasznosításának részletes felmérésével állapítható meg. A nemzetközi szakirodalom ennek ellenére igazolja az adatközlők által feltételezett jelenséget, a hód puhafa-preferenciáját (Nolet et al. 1994, Haarberg \& Rosell 2006, Vorel et al. 2015). Megjegyezzük, hogy Európa egyes térségeiben más nemzetségek preferálására is akad példa (Haarberg \& Rosell 2006, Vorel et al. 2015). Olykor pedig a kínálatban ritka fajok nagyarányú hasznosítása tapasztalható, amit a kiegészítő tápanyagok iránti igény magyarázhat (Nolet et al. 1994). Egyes szerzők említést tesznek nemzetségeken belüli, például füzfajok közti preferencia-különbségröl (Nolet et al. 1994), valamint a különböző átmérőjü törzsek és ágak hasznosításának mérté- 
kében tapasztalt eltérésekröl is (Haarberg \& Rosell 2006). E témakörökkel kapcsolatban az adatközlők gyakran ellentmondásos véleményeket fogalmaztak meg, melyek értelmezése a lokális kínálat ismeretének hiányában nehézségekbe ütközött. A kanadai hód táplálkozási stratégiájának feltárását célzó kutatások szerint a nagy törzsek kidöntése és feldolgozása energetikailag költségesebb, a vízparttól való távolság növekedésével a kidöntött törzsek átméröje csökkenést mutat, az átmérő-szelektivitás és annak távolsággal való kapcsolata pedig nemzetségenként is különbözhet (Jenkins 1980).

A hódrágás egyes élőhelyeken a vízparti fásszárú növényzet megfiatalodásához, bokros szerkezetűvé alakulásához vezethet a kidöntött egyedek sarjadásának következtében (Fustec et al. 2001, Jones et al. 2009), más élőhelyeken pedig az egyedek elpusztulása és kompetítor fajok jelenléte miatt fajösszetételbeli változást eredményezhet (Johnston \& Naiman 1990). A természetvédelmi szakemberek ezen természetvédelmi jelentőségű változásokkal kapcsolatban is figyelemre érdemes tapasztalatokkal, véleményekkel rendelkezhetnek, melyeket a jövőben szintén érdemes lesz vizsgálni.

A hódok lágyszárú fajokkal való táplálkozására terepi megfigyeléssel csak ritkán találhatunk bizonyítékot (megrágott vagy kihúzott növényi részek, élelemraktárba halmozás, a táplálkozó állat direkt megfigyelése), ezért ezzel kapcsolatban sok adatközlő nem rendelkezett tapasztalattal. Egyesek azonban nagyon értékes, egyedi, olykor nemzetközi szinten is új megfigyeléseket osztottak meg velünk öszszesen 19 lágyszárú taxon fogyasztásáról. A detektálás nehézsége ellenére néhány terepi vizsgálat alapján tudjuk azt, hogy az eurázsiai hód igen jelentős mértékben fogyaszthatja a vízben és a vízparton élő lágyszárú fajokat (Krojerová-Prokešová et al. 2010, Law et al. 2014).

A hódok táplálékösszetételének tudományos vizsgálata ürülékek, illetve elhullott példányok gyomortartalmának elemzésével, vagy táplálékválasztási kísérletekkel lehetséges. Egy kísérletben például Iris pseudacorus, Carex rostrata, Equisetum fluviatile és Menyanthes trifoliata fogyasztását igazolták, és a hódrágás terepi módszerekkel mérhető változásokat okozott a növényzetben, a diverzitás növekedését eredményezve (Law et al. 2014). Az eurázsiai hód számos egyéb lágyszárú taxont fogyaszthat még, csehországi mikrohisztológiai adatok szerint például az itt felsoroltakat: Achillea millefolium, Arctium tomentosum, Campanula sp., Carex sp., Cirsium sp., Galium sp., Juncus sp., Myriophyllum sp., Origanum sp., Petasites sp., Plantago sp., Polygonum sp., Potentilla sp., Urctica dioica, Verbascum sp., Viscum album, Zea mays (Krojerová-Prokešová et al. 2010). A természetes vízi és vízparti vegetáció kapcsán magyarországi közlemények korábban csak a Nuphar lutea és a Nymphaea alba fogyasztásáról számoltak be (Bozsér 2000), vizsgálatunk ehhez mindenképpen értékes adalékot szolgáltatott. 
Az adatközlök által jelzett hasznosítás szisztematikusan gyüjtött terepi adatokkal való megerősítése a fásszárú fajokon észlelhető rágásnyomok regisztrálásával ellentétben a lágyszárúak esetén mindenképpen nehezebb feladat lesz, mivel ehhez sok területről és több vizsgálati időszakból származó biológiai mintákra van szükség.

A faj rágási tevékenysége számos konfliktus forrása (Vorel et al. 2016, Czabán \& Gruber 2018). Ennek kapcsán Magyarországon elsősorban nemesnyár-ültetvényekben jelentkeznek káresemények, de a gyümölcsfák, díszfák kidöntése olykor szintén problémákhoz vezet (Czabán 2013, Juhász et al. 2019). A terményfogyasztás több európai országban jellemző, Csehországban elsősorban a kukorica, cukorrépa és a fiatal repce fogyasztása vezet konfliktushoz (Vorel et al. 2016). A termények, elsősorban pedig a kukorica begyüjtése kapcsán meglepően sok információt kaptunk adatközlőinktől, a jelenséget a megkérdezettek több mint fele ismerte. A szántóföldeken jelentkező hódkárt korábban a Kerka mentén is vizsgálták (Právics 2012), a kukorica hód általi begyüjtését a Dél-Alföldön vadkamera segítségével sikerült dokumentálni (Juhász 2018). A hód a kukoricatáblában jól kitaposott útvonalon, állandó csapáson közlekedik (Právics 2012). A kukoricát többnyire 5-10 méter átmérỏjü körökben teljesen letermeli, a körökön és csapásain kívül azonban jelentős taposást nem végez, ezért hatása könnyen megkülönböztethető a vadkártól (Juhász E., nem publikált adat). A termőföldeken okozott hódkár egyes természetvédelmi szakemberek szerint a vadkárnál jóval kisebb mértékü (Juhász et al. 2019).

\section{Épités}

A hód általi gátépítés egyes térségekben általánosan ismert jelenség, más térségekben ezzel szemben alig tapasztalható. Ennek következtében egyes adatközlők részletes információkat tudtak megosztani velünk a gátak szerepéről, kinézetéről, sőt az építőanyagokról is. Más adatközlők azonban számos hódterritórium megismerése ellenére sohasem találkoztak hódgáttal, ezért egy részük úgy vélte, hogy az építkezés az eurázsiai hódra nem jellemző. Ezt a meggyőződést a médiában szereplő téves információk is erősíthetik.

Az eurázsiai hód és az Európában idegenhonos inváziós kanadai hód (Castor canadensis) közös elterjedési területén végzett oroszországi vizsgálatokban a 20. század végén azt állapították meg, hogy a kanadai hód gát- és várépítési aktivitása nagyobb mértékü (Danilov és Kanshiev 1983). Ezt az eredményt sok nemzetközi publikáció mellett magyarországi tanulmányok is közölték (Bozsér 2001, Haarberg 2007, Bajomi 2011). Egy olyan kutatás azonban, amelyet ugyanabban a térségben, a hódok megtelepedésének későbbi fázisában folytattak, kimutatta, 
hogy azonos hidrológiai és geomorfológiai viszonyok esetén a két faj építkezési gyakoriságában nem igazolhatók különbségek (Danilov és Fyodorov 2015).

Az építkezés okai kapcsán az adatközlők többsége az adott vízfolyás tulajdonságaival és a partjelleggel kapcsolatos szempontokat emelt ki. Ezek meghatározó szerepét a nemzetközi szakirodalom is igazolja. Svédországi eredmények szerint az eurázsiai hódnak gátépítésre olyan helyeken van szüksége, ahol a 0,7-1 méteres, minimális vízmélység másként nem biztosítható (Hartman \& Törnlöv 2006). A várépítést, azaz a kotorék tetejének és bejáratának ágakkal való fedését pedig az élőhelyi adottságok és a vízszint változásai is befolyásolják (Müller-Schwarze 2011). A várak továbbá nem csak a ragadozókkal, hanem az extrém hőmérséklettel szemben is védelmet nyújtanak (Müller-Schwarze 2011).

Az eurázsiai hód által építésre használt fás- és lágyszárú növényfajokkal, valamint egyéb anyagokkal eddig kevés kutatás foglalkozott. Egy franciaországi vizsgálat azt mutatta ki, hogy a várépítésre használt ágak több mint fele Salix vagy Populus ág volt még azokon a területeken is, amelyeken nem ezek uralkodtak a kínálatban, és a vastagabb, a vár ,vázát” jelentő ágakat szinte kizárólag ezen fajok adták (Fustec \& Cormier 2007). A fajösszetétel és vegetációszerkezet építőanyagok kiválasztásában játszott szerepének tisztázásához a kutatást érdemes lenne más élőhelyeken, más országokban megismételni. Az adatközlők által is említett jellemzők közül az építmények iszappal való tapasztása és lágyszárú fajok, valamint egyéb anyagok beépítése ismert jelenség (Müller-Schwarze 2011), az építés során a faágak hosszú, lágyszárú növényekkel, például kukoricával való helyettesítése szintén (Vorel et al. 2016). Ezt az építkezési formát már Magyarországon is leírták (Právics 2012), valamint a Mura menti helyi lakosok ugyancsak ismerik (Juhász et al. 2017). Jelen vizsgálat adatközlői azonban 15 lágyszárú taxon felhasználásáról számoltak be, ezzel értékes, új adatokat szolgáltatva a témában.

A hódok, mint ökoszisztéma-mérnökök gátépítésükkel képesek táji léptékben megváltoztatni egyes vízfolyások jellegét (Naiman et al. 1986, Gorczyca et al. 2018). Nagyobb területek elárasztása esetén állóvízi élőhelyeket, „hódtavakat” és nedves gyepeket, „hódréteket” hozhatnak létre, ezzel pedig jelentős hatásokat gyakorolnak a területek flórájára, valamint gerinces és gerinctelen faunájára (Rosell et al. 2005, Law et al. 2017, Westbrook et al. 2011). A hód megjelenése emellett befolyásolja a táj által nyújtott ellátó, szabályozó és kulturális ökoszisztéma szolgáltatásokat, amit a tájban élő helyi lakosok is érzékelnek (Ulicsni et al. 2020). Mivel a gyakorlati természetvédelmi szakemberek ismerik, sőt néhányan közülük rendszeresen figyelemmel kísérik a hódok gátépítésével érintett helyszíneket, ezért jelentős segítséget nyújthatnak a visszaduzzasztás és elárasztás ökológiai, természetvédelmi következményeivel kapcsolatos jövőbeli vizsgálatok fókuszterületeinek kijelölésében. 
A hód élőhelyátalakító tevékenysége sok esetben ütközik a területek hasznosításával kapcsolatos emberi célokkal. A gátépítés és a kotorékok ásása egyaránt vezethet konfliktusokhoz (Vorel et al. 2016). A Kárpát-medencében is jellemzö, hogy a hódgátak hatására kaszálók, valamint egyéb, emberi hasznosítás alatt álló területek kerülnek víz alá (Czabán 2013, Juhász et al. 2017). A kotorékok pedig vízpart mellett futó földutak beszakadását eredményezhetik, továbbá - elsősorban keskeny hullámtér esetén - árvízvédelmi töltések szerkezetét gyengíthetik (Czabán \& Gruber 2018). Adatközlőink ezen hatásokkal kapcsolatos tudásanyagát és véleményeit tanulmányunk első részében ismertettük (Juhász et al. 2019).

\section{Élöhelyválasztás}

Az élőhelyválasztásról föként azok az adatközlők tudtak komplex véleményt formálni, akik a különböző folyó-, patak- vagy csatornaszakaszok elfoglalásának sorrendjét nyomon követték. Ennek oka, hogy a faj ma már az alkalmas élöhelyek döntő többségén megjelent (Juhász et al. 2019). A témakör megismerését tovább nehezíti az, hogy a hód a Kárpát-medencébe való visszatérése során meghatározott útvonalakon, Magyarországon elsősorban a nagy folyókról a kisvízfolyások irányába haladva jutott el az ország különböző víztesteire.

Csehországban, a Morva mentén a bokorfüzeseket és a füz-nyár ligeterdőket mind az élőhely, mind pedig a táplálkozóhely élőhelyen belüli kiválasztása során előnyben részesítette más társulástípusokhoz képest (John \& Kostkan 2009). Ugyanabban a vizsgálati térségben a puhafákban gazdag folyószakaszokat már a visszatelepülés korai fázisában elfoglalta, és az utakhoz vagy településekhez közelebb eső területeken jelent meg legkésőbb (John et al. 2010). Franciaországban, a Loire mentén minél nagyobb volt a Salix és Populus fajokból rendelkezésre álló kínálat, annál kisebbnek bizonyult az egyedek a mozgáskörzete (Fustec et al. 2001). Azt is kimutatták, hogy a várak és kotorékok 50\%-osnál nagyobb meredekségü partokon épültek, homokpadokon nem, továbbá a fásszárú növényzet borítása is szerepet játszott a hely kiválasztásában (Fustec et al. 2003). Ezen tudományos eredmények összhangban vannak adatközlöink többségének véleményeivel, sőt az interjúkból származó adatok és az interjúidézetek (2. függelék) tükrözik, hogy a megkérdezettek sok esetben törekednek az élőhely- és kotorékhelyválasztás ennél mélyebb megértésére is.

A magyarországi visszatelepítések idején a telepítési helyszínek kijelölésével kapcsolatban még kevés európai ajánlás állt rendelkezésre (Macdonald et al. 2000). Az észak-amerikai élőhelyalkalmassági modell (Allen 1983) és az európai modellek Kárpát-medencén belüli élőhelyekre való adaptálásának lehetőségét korlátozottnak ítélték meg (Haarberg 2007). A Tisza menti telepítések tervezésekor a következő kritériumokat tartották fontosnak: tartós a vízborítás; megfelelő 
fásszárú táplálékkínálat áll rendelkezésre a víztől számított 20 méteres távolságon belül; a meder nem kövezett, nem betonozott; a part meredeksége helyenként meghaladja a 45\%-ot, de nem szakadópart; a felső partél legalább 0,5-1 méterrel a „magas vízszint” felett van; a partot nem terheli jelentős gyalogos- vagy autóforgalom; a vízfolyás medrének esése $0-2 \%$, mélysége 2-3 m, és szélessége legalább 5 méter; a vízszint stabil; a víz nem intenzíven halászott; nincs jelentős motorcsónak-forgalom; a terület közutaktól, vasutaktól távolabb esik (Bozsér 2002, Haarberg-Bozsér 2005). Adatközlőink szerint a visszatelepítések fenti ajánlásokat részben alkalmazó gyakorlata egyes esetekben a faj tartós megtelepedését vonta maga után, több esetben azonban az egyedek hosszabb-rövidebb idő után elhagyták a telepítési helyszínt. Az Alsó-Tisza völgy holtágain elengedett hódok az elengedést követően a mentett oldalon és az élő folyón kerestek új élőhelyeket (Juhász 2018).

Adatközlőink tapasztalatai és terepi vizsgálatok eredményei (Czabán 2017, Juhász 2018, Buzetzky \& Juhász 2019) ma már azt mutatják, hogy a hód megtelepszik és magas, akár 5 család/10 fkm állománysürüséget is elérhet a jelentős vízszintingadozással bíró nagy folyóinkon is, tehát jól alkalmazkodik a vízszint szélsőséges változásaihoz. Gátépítésével pedig a sekély vízfolyásokat saját megtelepedésére alkalmassá teszi (Czabán 2016).

\section{Ismeretterjesztés és az adatközlök által érzékelt tudáshiány a helyi lakosság körében}

Helyi közösségekben a természettel kapcsolatos tudás kialakulásában fontos szerepe van a közösségen belüli tudásátadási mechanizmusoknak és a személyes tapasztalatoknak (Reyes-García et al. 2009, Guimbo et al. 2011). Az egyes fajokkal kapcsolatos jelenségek percepciójára és a konfliktusokra a média is jelentős hatást gyakorolhat (Gore \& Knuth 2009, Jemison 2017). A tudományos eredmények lakossággal, érdekcsoportokkal való megismertetése változást okoz a fajok ismeretében, valamint hozzájárulhat a konfliktusok mérsékléséhez (Espinosa \& Jacobson 2012).

Ahogy arról adatközlőink is beszámoltak, a magyarországi hód-visszatelepítések idején a telepítési helyszínek közelében, valamint néhány további kiválasztott területen lakossági tájékoztatás és ismeretterjesztő tevékenység zajlott. A WWF Magyarország és az OBI szervezésében megvalósult „hódórák” több mint 20 000 diákot szólítottak meg (Bajomi 2011). Minden telepítés esetén sor került egy sajtónyilvános elengedésre, ezekről újságok, televíziós és rádiómüsorok, valamint internetes portálok is hírt adtak (Bajomi 2011). Egyes magyar nyelvü, online kiadványok (Bozsér 2001, Haarberg 2007, Czabán 2013) a fajjal kapcsolatos ismeretszerzést a telepítési program lezárulása után is folyamatosan segítik. 
A hóddal kapcsolatos hagyományos ökológiai tudás a faj korábbi kipusztulását követően, másfél évszázad alatt szinte teljesen elveszett (Babai et al. 2019). Jelen vizsgálat adatközlőinek közel fele szerint a tudáshiány általános, a lakosság számottevő része azzal sincs tisztában, hogy a hód növényevő, sokan halfogyasztónak gondolják. Ezt a képet azonban árnyalja egy három tájban végzett kutatás eredménye, mely szerint a helyiek ugyan sok esetben nem tudják azt, hogy mi a fadöntés célja, vagy azt, hogy mit eszik a hód, mégis széleskörü tapasztalati tudással rendelkeznek a hód által megrágott fásszárú fajokkal és a hód életmódjának néhány egyéb aspektusával kapcsolatban (Juhász et al. 2017).

A helyi közösségek tagjai jobban ismerik a feltűnő tevékenységet folytató, a lakóhelyük közelében élő, a közösség életére potenciálisan hatást gyakorló, tehát például gazdasági károkat okozó, továbbá a kulturális jelentőséggel bíró állatfajokat (Ulicsni et al. 2019). Ugyanakkor a természettel való személyes kapcsolat, a tájban töltött idő és az életmód is befolyásolja a természetismeretet (Zarger 2002, Karjalainen \& Habeck 2004, Zent 2013). A hód esetén továbbá az élőhelyek jellege hatást gyakorolhat a megszerzett ismeretekre és a faj megítélésére: a nagyobb folyók hullámterében a hód tevékenysége olykor észrevétlen marad a laikus szemlélő számára (Juhász et al. 2019), a kisvízfolyásokon és a lakott területek közelében azonban annál szembeötlőbb, gyakran konfliktust generál (Czabán \& Gruber 2018). Továbbá az adatközlőktől származó információk alapján eltérések mutatkoznak abban a tekintetben, hogy hol milyen forrásokból és milyen hatékonyan tájékozódhatnak a helyiek a faj jelenlétéről, tevékenységéről. Mindezen okok miatt jelentős különbségek lehetnek a hód ismeretében a különböző térségek között és a térségeken belül is. Úgy véljük, a hódot a társadalom szélesebb rétegét megszólító kommunikáció során nem szükséges kiemelten kezelni, de életmódjának bemutatását mindenképpen érdemes integrálni a vizes élőhelyekkel kapcsolatos általános ismeretterjesztésbe.

\section{Általános megállapitások, ajánlások}

Az adatközlők a kérdések megválaszolásakor elsősorban a saját térségükben végzett megfigyeléseiket, személyes tapasztalataikat ismertették. Az interjúk segítségével nyert információk szakirodalmi környezetben való értelmezése jelentősen segítette a hazánkban élő hódok jobb megismerését. Az adatközlőknek az ország más részeire, egészére többnyire kevés volt a rálátásuk a vizsgált jelenségekkel kapcsolatban. Ez egyfelöl rámutat az ismeretek szintetizálásának szükségességre, ugyanakkor kétrészes tanulmányunk elkészítése során hozzájárult a térségek közti különbségek megismeréséhez, értelmezéséhez.

Egyes témakörök vizsgálatakor - ilyenek például a faj visszatérésének története, a konfliktusok és a faj helyiek általi ismerete - elsősorban a társadalomtudományos módszerekre támaszkodhatunk. Más kérdéscsoportok azonban ha- 
tékonyan kutathatók terepi módszerekkel. Ugyanakkor nagyszámú szakember megkérdezésével utóbbiakkal kapcsolatban is előkerülhetnek olyan, ritkán megfigyelhető jelenségek, melyek intenzívebb, de alkalmi és lokális terepi vizsgálatok során nem biztos, hogy észlelhetők. A jövőben érdemes lesz a Kárpát-medencében végzett, célirányos terepi vizsgálatokkal is megerösíteni minél több, az interjúkban elhangzott megállapítást. Az interjúkészítés nem csak a tapasztalati tudás összegyüjtését teszi lehetővé, hanem a módszer segítségével fény derül a szakembereket leginkább foglalkoztató kérdésekre, ami jelentősen segítheti az új kutatási irányvonalak kijelölését, és a későbbi vizsgálatok megtervezését.

A tanulmány első részében (Juhász et al. 2019) bemutatott ember-vadvilág konfliktusok témája kiemelten aktuális, ezek a problémák több társadalmi csoportot érintenek és jelentőségük a hód állományának gyarapodásával párhuzamosan növekszik. A konfliktusok mérséklésében a természetvédelmi szakemberek helyi szinten folytatott kommunikációs és ismeretterjesztési tevékenysége fontos szerepet játszhat, de a problémák országos szinten való kezeléséhez szakmaközi egyeztetésekre van szükség.

A hód állománya az Európa-szerte zajlott visszatelepítési programok következtében megerősödött. Ennek ellenére a faj ökoszisztéma-mérnök tevékenysége, élőhely-átalakító és élőhely-létrehozó képessége miatt továbbra sem kerülhet ki a természetvédelem fókuszából. A területek állapotának, flórájának és faunájának védelme érdekében terepi módszerekkel szükséges vizsgálni a hód ökológiai hatásait. Csak ilyen módon nyerhet megállapítást az, hogy milyen esetekben és miért fontos védeni a faj tevékenységét, vagy éppen ellenkezőleg, mikor szükséges egy-egy természetvédelmi szempontból kedvezőtlen következmény miatt beavatkozni.

Köszönetnyilvánítás - Szeretnénk köszönetet mondani adatközlőinknek: Albert András, Bajomi Bálint, Bártol István, Bátky Gellért, Czabán Dávid, Csór Sándor, Darányi László, Fülöp Tihamér, Fűzfa Zoltán, Gáborik Ákos, Gál Lajos, Gruber Ágnes, Gruber Tamás, Habarics Béla, Harsányi Dezső, Harsányi Krisztián, Hegyeli Zsolt, Herczeg Ferenc, Imecs István, Kleszó András, Kovács Zoltán, Kováts László, Lelkes András, Lontay László, Lovászi Péter, dr. Lőkkös Andor, Megyer Csaba, Mócsán András, Monoki Ákos, Mórocz Attila, Németh Árpád, Öze Péter, Peimli Piroska, Pellinger Attila, Petrovics Zoltán, Placzer Gábor, Právics Márk, Puskás József, Sallai Zoltán, Selmeczi Kovács Ádám, Seres Mihály Nándor, Sipos Tibor, Sugár Szilárd, Szabó Csaba, Szekeres Zsófia, Dr. Szinetár Csaba, dr. Tallósi Béla, Tamás Ádám, Terhes Attila, Tóth Mihály, Urbán László, Varju József, Zákány Albert és két anonim adatközlő. Köszönjük továbbá Bajomi Bálint, Czabán Dávid, Gruber Tamás és az adatközlök kiválasztásában részt vett személyek szakmai segítségét, a tíz magyarországi nemzeti park igazgatóság együttmüködését, valamint a WWF Magyarországnak a rendelkezésünkre bocsátott jelentéseket. Az Innovációs és Technológiai Minisztérium ÚNKP-19-3 kódszámú Új Nemzeti Kiválóság Programjának szakmai támogatásával készült. 


\section{Irodalomjegyzék}

Allen, A. W. (1982): Habitat suitability index models: Beaver. - US Department of the Interior, Fish and Wildlife Service Biological Report 82 (10.30 Revised), Washington, 20 p.

Babai D., Ulicsni V., Biró M., Juhász E. \& Molnár Zs. (2019): „Az emberek nem tudják miféle. Még emlékezet se volt róluk!” Természetismeret-szerzési mechanizmusok egy visszatelepített ökoszisztéma-mérnök faj (eurázsiai hód - Castor fiber) kapcsán. - Ethno-Lore. 36: 227-244.

Bajomi, B. (2011): Az eurázsiai hód (Castor fiber) visszatelepitésének tapasztalatai Magyarországon. - WWF Magyarország, Budapest, 54 p.

Bozsér O. (2000) A jót választani kell - Hódok Gemencen. - Élet és Tudomány 12: 368-370.

Bozsér, O. (2001): Hódok az óvilágban. - WWF Magyarország, Budapest, 28 p.

Bozsér, O. (2002): Hódélőhely alkalmassági felmérés a Közép-Tiszai Tájvédelmi Körzetben. WWF Magyarország, Budapest, 13 p.

Buzetzky, Gy. \& Juhász, E. (2019): Eurázsiai hódok (Castor fiber) a Dráva Baranya megyei szakaszán. - Kutatási jelentés. Duna-Dráva Nemzeti Park Igazgatóság, 6 p.

Campbell-Palmer, R., Schwab, G., Girling, S., Lisle, S. \& Gow, D. (2015): Managing wild Eurasian beavers: a review of European management practices with consideration for Scottish application. - Scottish Natural Heritage Commissioned Report No. 812. Scottish Natural Heritage, Inverness, United Kingdom, 51 p.

Czabán, D. (2003): A Hanságba visszatelepített hódok (Castor fiber) élöhely-és táplálékválasztási szokásai. - MSc diplomadolgozat, Eötvös Loránd Tudományegyetem, Budapest, 71 p.

Czabán, D. (2013): Éljünk együtt a hódokkal, de hogyan? - WWF Magyarország, Budapest, 41 p.

Czabán, D. (2016): Hódok a Szigetközben. - In: Korda, M. (szerk.): Az erdögazdálkodás hatása az erdők biológiai sokféleségére. Tanulmánygyüjtemény. Duna-Ipoly Nemzeti Park Igazgatóság, Budapest, pp. 403-418.

Czabán, D. (2017): A hód állományának vizsgálata az FHNP müködési területén. - Kutatási jelentés. Fertő-Hanság Nemzeti Park Igazgatóság, Sarród, Kézirat, 45 p.

Czabán, D. \& Gruber, T. (2018): Visszatértek a hódok - áldás vagy átok? - Termvéd Közlem. 24: 67-74. https://doi.org/10.20332/tvk-jnatconserv.2018.24.67

Danilov P. I. \& Kanshiev V. Y. (1983): The state of populations and ecological characteristics of European (Castor fiber L.) and Canadian (Castor canadensis Kuhl.) beavers in the north-western USSR. - Acta Zool. Fenn. 174: 95-97.

Danilov, P. I. \& Fyodorov, F. V. (2015): Comparative characterization of the building activity of Canadian and European beavers in northern European Russia. - Russ. J. Ecol. 46: 272-278. https:// doi.org/10.1134/S1067413615030029

Dzięciołowski, R. \& Misiukiewicz, W. (2002): Winter food caches of beavers (Castor fiber) in NE Poland. - Acta Theriol. 47: 471-478. https://doi.org/10.1007/BF03192471

Enck, J. W., Bishop, P. G., Brown, T. L. \& Lamendola, J. E. (1992): Beaver-related Attitides, Experiences, and Knowledge of Stakeholders in Wildlife Management Unit 21., 74 p.

Espinosa, S. \& Jacobson, S. K. (2012): Human-wildlife conflict and environmental education: Evaluating a community program to protect the Andean bear in Ecuador. - J. Environ. Educ. 43: 55-65. https://doi.org/10.1080/00958964.2011.579642

Fustec, J., Lodé, T., Le Jacques, D. \& Cormier, J. P. (2001): Colonization, riparian habitat selection and home range size in a reintroduced population of European beavers in the Loire. - Freshw. Biol. 46: 1361-1371. https://doi.org/10.1046/j.1365-2427.2001.00756.x

Fustec, J., Cormier, J. P. \& Lodé, T. (2003): Beaver lodge location on the upstream Loire River. Comptes rendus biologies 326: 192-199. https://doi.org/10.1016/S1631-0691(03)00057-X 
Fustec, J. \& Cormier, J. P. (2007): Utilisation of woody plants for lodge construction by European beaver (Castor fiber) in the Loire valley, France. - Mammalia 2007: 11-15. https://doi. org/10.1046/10.1515/MAMM.2007.002

Guimbo, I. D., Mueller, J. G. \& Larwanou, M. (2011): Ethnobotanical knowledge of men, women and children in rural Niger: a mixed-methods approach. - Ethnobot. Res. Appl. 9: 235-242.

Gorczyca, E., Krzemień, K., Sobucki, M. \& Jarzyna, K. (2018). Can beaver impact promote river renaturalization? The example of the Raba River, southern Poland. - Sci. Total Environ. 615: 1048-1060. https://doi.org/10.1016/j.scitotenv.2017.09.245

Gore, M. L. \& Knuth, B. A. (2009): Mass media effect on the operating environment of a wildlife related riskbcommunication campaign. - J. Wildl. Manage. 73(8): 1407-1413. https://doi. org/10.2193/2008-343

Haarberg-Bozsér, O. (2005): Hódélőhely alkalmassági felmérés az Alsó-Tisza-vidékén. - WWF Magyarország, Budapest, 13 p.

Haarberg, O. \& Rosell, F. (2006): Selective foraging on woody plant species by the Eurasian beaver (Castor fiber) in Telemark, Norway. - J. Zool. 270: 201-208. doi: http://doi.org/10.1111/j.14697998.2006.00142.x

Haarberg, O. (2007): Amit a hódról tudni érdemes. - WWF füzetek 26. WWF Magyarország, Budapest, $30 \mathrm{p}$.

Hartel, T., Fischer, J., Câmpeanu, C., Milcu, A. I., Hanspach J. \& Fazey, I. (2014): The importance of ecosystem services for rural inhabitants in a changing cultural landscape in Romania. - Ecol. Soc. 19: https://doi.org/10.5751/ES-06333-190242

Hartman, G. \& Törnlöv, S. (2006): Influence of watercourse depth and width on dam-building behaviour by Eurasian beaver (Castor fiber). - J. Zool. 268: 127-131. https://doi.org/10.1111/ j.1469-7998.2005.00025.x

Jemison, M. (2017): Communication considerations for one health: the influence of media framing on representations of a human-bat disease conflict in the Australian print media. - Aust. Zool. 38: 505-517. https://doi.org/10.7882/AZ.2017.002

Jenkins, S. H. (1980): A size distance relation in food selection by beavers. - Ecology, 61: 740-746.

Jones, K., Gilvear, D., Willby, N. \& Gaywood, M. (2009): Willow (Salix spp.) and aspen (Populus tremula) regrowth after felling by the Eurasian beaver (Castor fiber): implications for riparian woodland conservation in Scotland. - Aquat. Conserv. 19: 75. http://doi.org/10.1002/aqc.981

John, F. \& Kostkan, V. (2009): Compositional analysis and GPS/GIS for study of habitat selection by the European beaver, Castor fiber in the middle reaches of the Morava River. - Folia Zool. 58: 76-86.

John, F., Baker, S. \& Kostkan, V. (2010): Habitat selection of an expanding beaver (Castor fiber) population in central and upper Morava River basin. - Eur. J. Wildl. Res. 56: 663-671. https:// doi.org/10.1007/s10344-009-0361-5

Johnston C. A. \& Naiman R. J. (1990) Browse selection by beaver: effects on riparian forest composition. - Can. J. For. Res. 20: 1036-1043. https://doi.org/10.1139/x90-138

Juhász, E. (2017): Az eurázsiai hód (Castor fiber) táplálék-preferenciájának és területhasználatának vizsgálata. - OTDK dolgozat, Szegedi Tudományegyetem, $39 \mathrm{p}$.

Juhász, E., Babai, D., Biró, M., Molnár, Zs. \& Ulicsni, V. (2017): Az eurázsiai hód (Castor fiber) táplálkozási és fásszárú-használati szokásaival kapcsolatos helyi tudás két évtizeddel a visszatelepítések kezdete után a Kárpát-medencében. - Termvéd. Közlem. 23: 182-200. https://doi.org/10.20332/tvk-jnatconserv.2017.23.182

Juhász, E. (2018): Az eurázsiai hód (Castor fiber Linnaeus, 1758) elterjedése és tevékenysége a Dél-Alföldön - Állattani Közlem. 103: 15-32. https://doi.org/10.20331/AllKoz.2018.103.1-2.15 
Juhász E., Biró M., Ulicsni V. \& Molnár Zs. (2019): Természetvédők és kutatók ismeretei az eurázsiai hód kapcsán a Kárpát-medencében I.: elterjedés, életnyomok, az együttélés lehetőségei, az elhullás okai. - Termvéd Közlem. 25: 59-79. https://doi.org/10.20332/tvk-jnatconserv.2019.25.59

Karjalainen, T. P. \& Habeck, J. O. (2004): When'the environment'comes to visit: local environmental knowledge in the far north of Russia. - Environ. Values 2004: 167-186.

Krojerová-Prokešová, J., Barančeková, M., Hamšíková, L. \& Vorel, A. (2010): Feeding habits of reintroduced Eurasian beaver: spatial and seasonal variation in the use of food resources. $-J$. Zool. 281: 183-193. https://doi.org/10.1111/j.1469-7998.2010.00695.x

Law, A., Jones, K. C. \& Willby, N. J. (2014): Medium vs. short-term effects of herbivory by Eurasian beaver on aquatic vegetation. - Aquat. Bot. 116: 27-34. http://doi.org/10.1016/j. aquabot.2014.01.004

Law, A., Gaywood, M. J., Jones, K. C., Ramsay, P. \& Willby, N. J. (2017): Using ecosystem engineers as tools in habitat restoration and rewilding: beaver and wetlands. - Sci. Total Environ. 605: 1021-1030. https://doi.org/10.1016/j.scitotenv.2017.06.173

Macdonald, D. W., Tattersall, F. H., Rushton, S., South, A. B., Rao, S., Maitland, P. \& Strachan, R. (2000): Reintroducing the beaver (Castor fiber) to Scotland: a protocol for identifying and assessing suitable release sites. - Animal Conservation forum 3: 125-133. https://doi. org/10.1111/j.1469-1795.2000.tb00237.x

Mátrai, B. (2019): Az eurázsiai hód (Castor fiber) táplálkozásának vizsgálata Budapesten. - Szakdolgozat, Szent István Egyetem, 37 p.

McKinstry, M. C. \& Anderson, S. H. (1999): Attitudes of private-and public-land managers in Wyoming, USA, toward beaver. - Environ. Manage. 23: 95-101. https://doi.org/10.1007/ $\underline{\mathrm{s} 002679900170}$

Müller-Schwarze, D. (2011). The beaver: its life and impact. - Cornell University Press, 216 p.

Naiman, R. J., Melillo J. M. \& Hobbie J. E. (1986): Ecosystem alteration of boreal forest streams by beaver (Castor canadensis). - Ecology 67: 1254-1269. https://doi.org/10.2307/1938681

Newing, H. (2010). Conducting research in conservation: social science methods and practice. Routledge, London and New York, 376 p.

Nolet, B. A., Hoekstra, A. \& Ottenheim, M. M. (1994): Selective foraging on woody species by the beaver Castor fiber, and its impact on a riparian willow forest. - Biol. Conserv. 70: 117-128. http://doi.org/10.1016/0006-3207(94)90279-8

Payne, N. F. \& Peterson, R. P. (1986): Trends in complaints of beaver damage in Wisconsin. - Wildl. Soc. Bull. (1973-2006), 14: 303-307.

Právics, M. (2012): Az eurázsiai hód (Castor fiber) állományának és táplálkozásának vizsgálata a Kerka mentén. - Szakdolgozat, Nyugat-Magyarországi Egyetem, 72 p.

Reyes-García, V., Broesch, J., Calvet-Mir, L., Fuentes-Peláez, N., McDade, T. W., Parsa, S., Tanner, S. Huenca, T., Leonard, W.R., Martínez-Rodríguez, M. R. \& TAPS Bolivian Study Team (2009): Cultural transmission of ethnobotanical knowledge and skills: an empirical analysis from an Amerindian society. - Evol. Hum. Behav. 30: 274-285. https://doi.org/10.1016/j.evolhumbehav.2009.02.001

Rosell, F., Bozser, O., Collen, P. \& Parker, H. (2005): Ecological impact of beavers Castor fiber and Castor canadensis and their ability to modify ecosystems. - Mammal rev, 35: 248-276.

Santo, A. R., Guillozet, K., Sorice, M. G., Baird, T. D., Gray, S., Donlan, C. J. \& Anderson, C. B. (2017): Examining private landowners' knowledge systems for an invasive species. - Hum. Ecol., 45: 449-462. https://doi.org/10.1007/s10745-017-9920-7

Tallósi, B. (2013): A betelepitett hódpopulációra vonatokozó megfigyelési adatok és a faj természetvédelmi helyzete a Hortobágyi Nemzeti Park Igazgatóság Közép-Tisza-Jászság Természetvédelmi Tájegységének területén 2012 decembere és 2013 márciusa között. - Kézirat, WWF Magyarország, Budapest, 28 p. 
Ulicsni, V., Babai, D., Vadász, Cs., Vadász-Besnyői, V., Báldi, A. \& Molnár, Zs. (2019): Bridging conservation science and traditional knowledge of wild animals: The need for expert guidance and inclusion of local knowledge holders. - Ambio, 48: 769-778. https://doi.org/10.1007/ s13280-018-1106-Z

Ulicsni. V., Babai, D., Juhász, E., Molnár, Zs. \& Biró, M. (2020): Local knowledge about a newly reintroduced, rapidly spreading species (Eurasian beaver) and perception of its impact on ecosystem services. - Plos One, 15: e0233506. https://doi.org/10.1371/journal.pone.0233506

Valachovič, D. (2014): Manual of beaver management within Danube River basin. Danube Parks, $76 \mathrm{p}$.

Varju, J. \& Jánoska, F. (2015): Az eurázsiai hód (Castor fiber Linnaeus, 1758) fás szárú táplálékpreferenciája és élőhelyhasználata a Mosoni-Dunán. - Erdészettudományi Közlem. 5: 129-144. https://doi.org/10.17164/EK.2015.009

Vorel, A., Válková, L., Hamšíková, L., Maloň, J. \& Korbelová, J. (2015): Beaver foraging behaviour: Seasonal foraging specialization by a choosy generalist herbivore. - Behav. Ecol. Sociobiol. 69: 1221-1235. https://doi.org/10.1007/s00265-015-1936-7

Vorel, A., Dostál, T., Uhlíková, J., Korbelová, J. \& Koudelka, P. (2016): Handbook for Coexisting with beavers. - Czech University of Life Sciences, Prague, $136 \mathrm{p}$.

Westbrook, C. J., Cooper, D. J. \& Baker, B. W. (2011): Beaver assisted river valley formation. River Res Appl. 27: 247-256. https://doi.org/10.1002/rra.1359

Wright J. P., Jones C. G. \& Flecker A. S. (2002): An ecosystem engineer, the beaver, increases species richness at the landscape scale. - Oecologia 132: 96-101. http://doi.org/10.1007/s00442002-0929-1

Zarger, R. K. (2002): Acquisition and Transmission of Subsistence Knowledge by Q'eqchi' Maya in Belize. - In: Stepp J. R., Wyndham F. S. \& Zarger R. K. (eds.): Ethnobiology and Biocultural Diversity. University of Georgia Press, Athens, GA., pp. 592-603.

Zent, S. (2013): Processual perspectives on traditional environmental knowledge. - In: Ellen R., Lycett S. J. \& Johns S. E. (eds.): Understanding Cultural Transmission in Anthropology: A Critical Synthesis. Berghahn Books, New York and Oxford pp. 213-265.

Internetes hivatkozások:

http1: http://magyarnemzetiparkok.hu/Utolsó letöltés időpontja: 2020. április 3. 


\title{
Knowledge of nature conservationists and researchers in the Carpathian Basin associated with the Eurasian beaver II: food choice, building activity, habitat selection of the species, communication about beavers
}

\author{
Erika Juhász ${ }^{1}$, Marianna Biró², Dániel Babai ${ }^{3} \&$ Zsolt Molnár $^{2}$ \\ ${ }^{1}$ Eötvös Loránd University, Department of Plant Systematics, Ecology and Theoretical \\ Biology, H-1117 Budapest, Pázmány P. stny. 1/C, Hungary \\ ${ }^{2}$ Centre for Ecological Research, Institute of Ecology and Botany, \\ H-2163 Vácrátót, Alkotmány u. 2-4., Hungary \\ ${ }^{3}$ Research Centre for the Humanities, Institute of Ethnology, \\ H-1097 Budapest, Tóth Kálmán u. 4, Hungary \\ E-mail:_erikamaria.juhasz@gmail.com
}

\begin{abstract}
We examined the knowledge of local nature conservationists and researchers associated with the Eurasian beaver through interviews. In the first part of our study (Juhász et al. 2019), we reported the spread of the beaver, recognisable beaver signs, possibilities of human-beaver coexistence and causes of mortality. In the second part (present paper), we show the answers to the questions related to the beaver's behaviour, communication about beavers, and perceptions about local inhabitants' knowledge. The informants observed the utilization of woody species belonging to 26 genera, the consumption of 19 herbaceous taxa, and the building of 15 herbaceous taxa into beaver dams and lodges. Furthermore, we gathered detailed information about the relation between habitat conditions and beaver activity (dam building, lodge construction and habitat selection). Data from the interviews about the beaver's behaviour can be a good complement to the results of field surveys, as well as help to better understand certain phenomena and to lay the foundations for new field research. The gaps in the knowledge of local people reported by the informants highlight that beavers' habits and effects should definitely be included in the general education about wetlands.
\end{abstract}

Keywords: Castor fiber, expert knowledge, structured interview, ecosystem engineer, reintroduction 